\title{
Effect of Strategic Marketing on Sustainable Business Performance-A Study of Pharmaceutical Industries in India
}

\author{
Aindrila Biswas* \\ Assistant Professor, Kabi Jagadram Roy Government General Degree College, Mejia, West Bengal, INDIA.
}

\begin{abstract}
Background: Concern over sustainability awakened firms to take responsive strategies and propagate sustainability. The present study tries to enumerate the role of strategic marketing orientation classified as market-orientation and innovation orientation on sustainability in business performance. Materials and Methods: Data was collected using structured questionnaires. The empirical model was tested using structural equation modeling. Results and Conclusion: The results suggest that innovation-orientation has maximum leverage on sustainability in environmental performance and market-orientation has maximum leverage on sustainability in economic performance of pharmaceutical industries.
\end{abstract}

Key words: Sustainability in performance, Strategic market orientation, Strategic innovation orientation, Environmental downturn, Economic performance.

\section{INTRODUCTION}

Sustainability has been an emerging issue for strategic business decisions over the past decade, pertaining to rising environmental concern and effective strategies such as green manufacturing, green marketing, green consumption needed for tackling the environmental downturn. The adoption of strategic green business practices help companies to meet regulatory environmental standards and undertake innovative practices in their manufacturing and marketing activities. ${ }^{1}$ Strategic marketing efforts are intrinsic towards successful management of business practices. ${ }^{2}$ With the current situation emphasizing the urgency to take substantive steps for tackling of environmental problems, the study of a relationship analysis between strategic marketing and sustainable business performance has thus been necessitated. ${ }^{3}$ The present study examines the influence of the two strategic marketing concepts- market orientation ${ }^{4}$ and innovation orientation ${ }^{5}$ on sustainable business performance. As sustainable business performance is a complex phenomenon, the model has been framed taking into consideration economic, environmental and social sustainability factors. ${ }^{6}$ Globalization, resource crisis, environmental pollution has led to stakeholders' awareness to focus on sustainability issues and to undertake responsible initiatives such as cleaner production, corporate social responsibility, corporate sustainability through strategic orientation. ${ }^{7,8}$ There is a dearth of studies encompassing and addressing all aspects of sustainability issues. ${ }^{8}$ Innovation is considered as the key element is strengthening a firms' competitive advantage. Firms' different strategic orientation such as strategic innovation orientation and strategic market orientation are an integral part of the learning, development and long term orientation and goal which cannot be attained by exclusion of exogenous sustainability concerns for the survival of business, society and environment pertaining to the vicious cyclic relation among the three.
Submission Date: 21-03-2018; Revision Date: 14-08-2018; Accepted Date: 22-10-2018

DOI: 10.5530/ijper.53.1.4 Correspondence: Aindrila Biswas, Assistant Professor, Kabi Jagadram Roy Government General Degree College, Mejia-722143, INIDA. Phone: +919051671307 E-mail: baindrila18@gmail. com

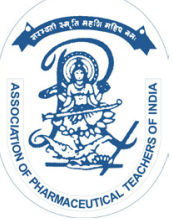

www.ijper.org 
The emerging countries are the driving factor in inducing the growth of the health and wellness industry such as pharmaceutical industry. The emerging countries have been estimated to contribute almost 30\% towards the market share growth of pharmaceutical industries by 2019. ${ }^{10}$ Pharmaceutical industry is defined as the industry engaged in the process of inventing, developing, manufacturing and administering the drugs manufacturing process by both public and private entities both individually and collaboratively. ${ }^{10}$

The aim of this paper is to contribute an understanding of the sustainability performance covering all three sustainability issues - Social, economic and environmental in pharmaceutical industry owing to the importance of such industry in the economic and infrastructural development of emerging countries like India.

The study tries to examine the influence of strategic marketing activities on sustainable business performance based on a conceptual model on a virtual sample of Indian companies. In the following section, the theoretical framework has been developed with the formulation of research hypotheses. Section 3 explains the research methodology followed by the empirical analysis in section 4. Finally, the discussions of the results and conclusions are presented in the final section of the study.

\section{Theoretical Background}

Orientation encompasses market orientation, technological, entrepreneurial and learning orientation. Strategic marketing refers to stakeholders' long-term orientation to optimize firms' value towards augmentation of competitive advantages and innovation practices, guiding firms' marketing activities. ${ }^{11}$ They are deeplyrooted in firms' value dimensions and reflecting directions implemented by management for the sake of superior performance. In this purview strategic marketing has been defined as stakeholders' orientation to focus on the long-term goal of firms' value-addition through environmental-friendly practices and innovation. Studies have found that the relationship between market orientation and business performance has been moderated by the presence of environmental variables. ${ }^{12}$ Similarly, market-orientation and innovation-orientation have been found to positively impact each other. ${ }^{13}$ Marketorientation and innovation orientation are the two integral parts of strategic marketing. ${ }^{14}$ Innovation orientation reflects strategic actions towards generation or adoption of new ideas with regard to product or process development. ${ }^{13}$ Effectiveness in business performance results from undertaking strategic marketing activities. ${ }^{15}$ The leveraging effects of business performance relies on strategic marketing orientations in the presence of business environmental factors such as socio-political factors, market dynamics and environmental apprehension acting as moderating variables. ${ }^{16}$

Many forms of strategic orientation have been discussed in literature but the present focus of practitioners is on strategic innovation orientation. ${ }^{17}$ Many studies have cited the relation between strategic orientation and performance outcomes. ${ }^{17-18}$ The present study has incorporated strategic market orientation and strategic innovation orientation as prognosticators and antecedents for attaining sustainability in performance. The study does not aim to analyze the interrelationship among the three sustainability parameters as they are three unique dimensions stressing on three different aspects- environment, economy and society. The three sustainability dimensions are fundamentally different that potentially require the consideration of different attributes, designs and perspectives for implementation. ${ }^{19}$ The social dimension of sustainability deals with the impact that an organizational activity will have on the social system where it operates, likewise the economic dimension refers to the impact an organization have on its shareholders, customers and potential buyers at local, national and international level. ${ }^{19}$ The economic dimension would intensify long term profitability, market standing, firm value creation, improved return to shareholders to remain in competition and more. ${ }^{19}$ On the contrary achieving sustainability in environmental performance would mean improved environmental management practice, improved product and service quality, pollution and waste control, optimal resource usage and creation of green image. ${ }^{19-20}$

\section{Strategic Market Orientation}

Strategic market orientation comprises of customerorientation and competitor-orientation with long-term goal of profit maximization focusing on customer needs and market opportunities. ${ }^{21-22}$ Strategic Market orientation means firms' managers' recognition of the need to focus on stakeholders' orientation- customer satisfaction, environmental management initiative and shareholder's value creation to achieve market standing and to remain in competition. Green market orientation focusing on environmental concern determines firm's degree of responsiveness to adjust to long term organizational goals and environmental initiatives to attain customer satisfaction realizing the need to protect the environment to gain consumer confidence. ${ }^{20}$ Several studies have been conducted on green market orientation, its antecedents and stakeholders' orientation. ${ }^{20}$ However, the present study transcends beyond analyzing the antecedents of strategic orientation parameters but 
how such indicators improve firm performance across all three sustainability parameters thus needs attention.

\section{Strategic Innovation Orientation}

Firms' success can largely be resorted to firms' capacity to engage in innovative practices such as product innovation, process innovation and development of technological capabilities. ${ }^{13}$ Strategic innovation orientation largely relies upon the knowledge structure for identification of market dynamics and eventual development or modification in business capabilities providing leverage to firms' overall performance. ${ }^{5}$ Companies with higher exposure to innovative capabilities tend to perform better than their less innovative counterparts. ${ }^{23}$ For the past few decades firms are increasingly facing the challenge to manufacture and market environment friendly products owing to sway of customers preferences towards environment friendly alternatives. ${ }^{20,24-25}$ Thus the need to perform in an environmentally sustainable manner by firms is becoming irrefutable. Sustainability in environmental performance can be attained through superior product innovation, improvement in product quality, process innovation, research and development, waste minimization, resorting to alternative resources, incorporation of environmentally amenable techniques in its operations. ${ }^{18,20}$ Role of innovation to accomplish sustainability in performance is inevitable. ${ }^{18}$

A firm can withstand competition through diversification, modernization, up gradation and innovation. Innovation forms and integral part in a firms sustained long term market standing and performance. Through innovation learned knowledge and competencies are utilized to offer better solutions, meet new and changing economic, social and environmental needs. ${ }^{19}$ From the above discussion the need to study the sustainability in performance outcomes based on the two strategic motivators needs further deliberation.

\section{Sustainability in Performance}

Sustainability is a subject of utmost importance in the present scenario pertaining to increasing stakeholders' responsibility towards environment. However stakeholders often face the challenge of measuring the firms' sustainability performance directly., ${ }^{8,26}$ The three tier perspective of sustainability issues are environmental integrity, social equity and economic prosperity forming integration between economy, environment and society. ${ }^{27}$

Rapid economic growth has triggered over-consumption and over-exploitation of natural resources resulting in environmental downturn. The term sustainability has been coined as the ability of the present generation to meet their needs without compromising with the needs of the future generations. ${ }^{28-29}$ Sustainability is a three dimensional concept including economic, environmental and social dimensions of performance at the company level..$^{30}$ Economic performance relies on firms' profitability, market-standing, increase in productivity and market-share with a long term orientation. ${ }^{31}$ The concern over sustainability has necessitated firms to focus on non-financial issues such as social activities and environmental protection initiation in their strategic action plan. ${ }^{32}$ The major antecedents of environmental performance are reduced energy and resource use, decreased emission of waste and pollutants and that of social performance being business ethics, community relations and employment. ${ }^{31}$ Companies tend to engage themselves in a variety of social, environmental and economic activities to attain sustainability in performance.

A wide array of social performance may include actions taken to address the interest of various social groups and communities where they operate, ensuring fair treatment of employees, conducting socio-cultural activities. ${ }^{19}$ Economic performance resorts to increased market value, competitive advantage, ensuring long term shareholders' value reducing costs and risks. ${ }^{19}$ And likewise environmental performance ultimately aims to reduce environmental deterioration through environment friendly product and process management. ${ }^{18}$ Studies have assessed the impact of strategic parameters on individual sustainability performance outcome individually however studies considering all aspects of sustainability from the perspective of strategic orientation needs to be studied.

Therefore it can be hypothesized that:

H1a: Strategic market orientation has a positive relation with sustainability in environmental performance.

H1b: Strategic market orientation has a positive relation with sustainability in economic performance.

H1c: Strategic market orientation has a positive relation with sustainability in social performance.

H2a: Strategic innovation orientation has a positive relation with sustainability in environmental performance. H2b: Strategic innovation orientation has a positive relation with sustainability in economic performance.

H2c: Strategic innovation orientation has a positive relation with sustainability in social performance.

\section{Research Methodology Data Collection}

A survey was conducted using structured questionnaires for testing of hypotheses. The survey instrument was divided into five modules based on the five constructs of the study. The potential respondents were informed 
about the objective of the study to ensure informed and quality responses and also assured about the confidentiality and anonymous treatment to be given to the data collected. The empirical data for the study was collected from various employees, managers, agents, representatives and intermediaries of different pharmaceutical companies in India engaged in different scales of production and offering different variety of pharmaceutical drugs inclusive of generic, herbal and ayurvedic products together generating valid 87 responses. Owing to the indispensable importance of pharmaceutical industries in nation building, survival of human beings, human health and environment pertaining to the increased demand for environment friendly herbal products and medicines without toxic chemicals the study thus confined its sample study to the various representatives of pharmaceutical industry. The measurement instrument was tested and validated. To ensure validity and reliability, the items were derived and modified from past studies and industrial interviews. ${ }^{18,19}$

\section{Measurement Instrument}

Responses were measured using a validated likert scale ranging from 1 strongly disagree to 5 strongly agree to measure perceptions towards strategic marketing and innovation practices and relevance on sustainability in performance.

\section{ANALYSIS AND RESULTS}

\section{Psychometric Properties of Scale}

The result of exploratory factor analysis has shown that all the items have factor loadings higher than the minimum threshold value of 0.50 . The cronbach's alpha coefficient ranging between 0.60 and 0.73 signifies substantive reliability of scale. Convergent validity and cronbach's alpha demonstrated convergent validity and internal consistency. In Table 1 the model properties of the five constructs has been presented. Average Variance Extracted (AVE) value close to or above 0.50 demonstrated discriminant validity for each construct.

\section{Structural Model}

A structural equation modeling from a confirmatory perspective has been applied to test the hypothesized model. Data analysis was done through the application of AMOS 20.0. The model fit indices have been presented in Table 2. The absolute fit indices used to evaluate the overall model includes Chi-Square/df (CMIN/df) statistics of 1.66, the Root Mean Square Error of Approximation (RMSEA) value of 0.07 used as the major misfit index, being less than 0.10 indicates
Table 1: Psychometric properties of the scale.

\begin{tabular}{|c|c|c|c|}
\hline Constructs & Loading & $\begin{array}{c}\text { Cronbach's } \\
\text { alpha }\end{array}$ & $\begin{array}{c}\text { Average } \\
\text { Variance } \\
\text { Extracted }\end{array}$ \\
\hline $\begin{array}{c}\text { Strategic market } \\
\text { orientation (SMO) }\end{array}$ & 0.63 & 0.53 \\
\hline SMO1 & 0.70 & 0.66 & 0.54 \\
\hline SMO2 & 0.80 & & \\
\hline SMO3 & 0.78 & & \\
\hline $\begin{array}{c}\text { Strategic innovation } \\
\text { orientation (SIO) }\end{array}$ & 0.73 & & \\
\hline SIO1 & 0.69 & & \\
\hline SIO2 & 0.51 \\
\hline SIO3 & 0.73 & \\
\hline $\begin{array}{c}\text { Sustainability in } \\
\text { environmental } \\
\text { performance } \\
\text { (SEnP) }\end{array}$ & 0.73 & & \\
\hline SEnP1 & 0.62 & & \\
\hline SEnP2 & 0.60 & & \\
\hline SEnP3 & 0.89 & & \\
\hline $\begin{array}{c}\text { Sustainability } \\
\text { in economic } \\
\text { performance } \\
\text { (SEcP) }\end{array}$ & 0.60 & \\
\hline SEnP1 & 0.75 & \\
\hline $\begin{array}{c}\text { SEnP2 } \\
\text { Social performance } \\
\text { (SScP) }\end{array}$ & 0.79 & & \\
\hline SScP1 & & & \\
\hline SScP2 & & & \\
\hline SScP3 & & & \\
\hline SScP4 & 0.70 & & \\
\hline
\end{tabular}

SMO- Strategic market orientation, SIO- Strategic innovation orientation, SECPSustainability in economic performance, SEnP-Sustainability in environmental performance, SScP- Sustainability in social performance

Source- Author's own findings

good fit and the goodness-of-fit index (GFI) of 0.91 and composite fit index of 0.92 both substantiates model validity. ${ }^{33}$ Thus, the indices suggest reasonable model fitness for the measurement model for effective estimation and interpretation of the parameter estimates. The results of hypothesized paths have been presented in Table 3 and Figure 1.

\section{DISCUSSION AND CONCLUSION}

The results suggest a significant association between strategic market orientation and innovation orientation with sustainability in environmental, economic and social performance of pharmaceutical industries. Development of market for ayurvedic and herbal medicines 


\begin{tabular}{|c|c|c|}
\hline \multicolumn{3}{|c|}{ Table 2: Fit indices for the overall model. } \\
\hline Index & $\begin{array}{c}\text { Structural model } \\
\text { Value }\end{array}$ & $\begin{array}{c}\text { Recommended } \\
\text { Value }\end{array}$ \\
\hline $\mathrm{X} 2$ /d.f & 1.66 & $<3$ \\
\hline RMSEA & 0.07 & $<0.10$ \\
\hline GFI & 0.91 & $\geq 0.90$ \\
\hline CFI & 0.92 & $\geq 0.90$ \\
\hline
\end{tabular}

Source- Author's own findings

\section{Table 3: Standardized regression coefficients.}

\begin{tabular}{|c|c|c|}
\hline Path & Estimate & Hypotheses \\
\hline$(\mathrm{H} 1 \mathrm{a}) \mathrm{SMO} \longrightarrow \mathrm{SEnP}$ & $0.45^{\star *}$ & (H1a) Supported \\
\hline$(\mathrm{H} 1 \mathrm{~b}) \mathrm{SMO} \longrightarrow \mathrm{SEcP}$ & $0.56^{* *}$ & (H1b) Supported \\
\hline$(\mathrm{H} 1 \mathrm{c}) \mathrm{SMO} \longrightarrow \mathrm{SScP}$ & $0.35^{*}$ & (H1c) Supported \\
\hline$(\mathrm{H} 2 \mathrm{a}) \mathrm{SIO} \longrightarrow \mathrm{SEnP}$ & $0.59^{* *}$ & (H2a) Supported \\
\hline$(\mathrm{Hbb}) \mathrm{SIO} \longrightarrow \mathrm{SEcP}$ & $0.37^{*}$ & (H2b) Supported \\
\hline$(\mathrm{H} 2 \mathrm{c}) \mathrm{SIO} \longrightarrow \mathrm{SScP}$ & -0.3 & (H2c) Not Supported \\
\hline
\end{tabular}

SMO- Strategic market orientation, SIO- Strategic innovation orientation, SECPSustainability in economic performance, SEnP- Sustainability in environmental performance, SScP-Sustainability in social performance. Source- Author's own findings

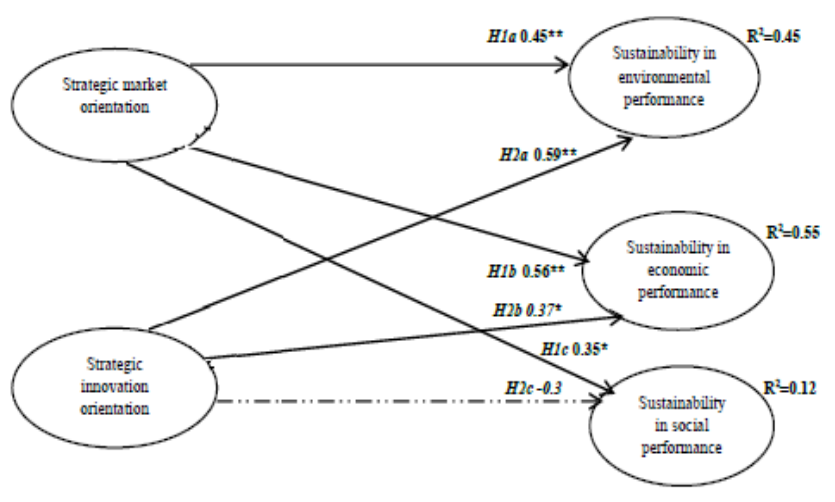

Figure 1: The structural model.

as green alternatives will have limited health hazards and environmental impact. However, strategic innovation orientation has been found to have insignificant impact of sustainability in social performance of a firm. The variance in sustainability in both environmental $\left(\mathrm{R}^{2}=0.45\right)$ and economic $\left(\mathrm{R}^{2}=0.55\right)$ performance of a firm has been found to be largely triggered by their strategic action plans through market and innovation orientation. The study has provided two most significant results in the context of business performance.

The study's primary contribution is to shed some light on the nexus among the two major strategic drivers and the three sustainability performance outcomes. Past studies have suggested the bidirectional or unidirectional relation between a strategic driver and a specific performance outcome mostly not considering all three sustainability performance outcomes simultaneously and highlighting the impact and role of corporate social responsibility in the context. ${ }^{19}$ The study concords with the findings of previous studies of high relevance in the context where a close association has been observed between strategic orientation and firms' performance however the method of study, modeling framework, objectives and findings do not identically replicate them. ${ }^{8,19-20}$ With respect to the H1a, H1b and H1c (Table 3, Figure 1) the significance and relevance of strategic market orientation as a driver to induce sustainable business performance across all the three dynamics has been supported. The strategic market dynamics play a decisive role in long term market standing, market value creation, firm goodwill creation, building of green image, recognition of customer expectations and preferences and on societal and social welfare of the stakeholders. To gain customer confidence and retain the existing customers, establishing relation with potential buyers, exploring new markets and optimizing market share and market growth as the primary objectives of strategic market orientation will inevitably boost sustainability in business performance as business, environment and society are intertwined. Pharmaceutical companies recognizing the value of this intertwined relationship and exogenous factors thus makes earnest endeavor to achieve economic (0.56), environmental (0.45) and social sustainability (0.35) in business performance. A firm usually resorts to diversification, modernization and innovation to remain in competition. Strategic innovation orientation with zeal to make and offer better products and service, superior research and development, product and process innovation, control in waste and resource usage would enable a firm to achieve sustainability in performance as has been substantiated by $\mathrm{H} 2 \mathrm{a}$ (0.59) and $\mathrm{H} 2 \mathrm{~b}$ (0.37) (Table 3, Figure 1). Strategic innovation orientation does not significantly influence sustainability in social performance which may be because innovation usually has a stronger inclination towards improvement in environmental and economic performance. The impact of superior innovation on social systems is irrefutable. Likewise innovations may not have feasible implications and applications without employee training and superior training would improve quality of human capital. However, notwithstanding this limitation, the study tries to assess the nexus between sustainability in performance and strategic orientation drivers from the perspective of pharmaceutical indus- 
tries. Effective strategies with regard to market orientation with a long-term perspective strongly propagate the profitability, market-standing and market share of a firm. Enhancement in earning capability may influence firms' to incorporate even better and improved mechanism to ensure sustained future growth and may foster better accountability towards the stakeholders. On the contrary, effective product, process or technological innovation improves the environmental performance of a firm. By undertaking innovation-orientation strategies, the management plans to optimize their resource and energy use, reduce emission of pollutants and harmful effluents, resorts to recycling of end-products at the disposal stage and also may plan to implement clean technology mechanism in their operation and production system to minimize the impact on environment. The result that strategic innovation orientation has no impact on social performance can be reasoned as sustainability in social performance of a firm may depend on their corporate citizenship practices, thus the likelihood of the adoption or development of new ideas, practices or processes in the phase of operation or marketing has little or no impact on discharge of societal responsibilities. Strategic market orientation has high impact on sustainability in environmental and social performance as with effective estimation and satisfaction of market demand, employment opportunities can be generatedand for want of betterment of company image, environmental initiatives can be taken by the management.. Thus both strategic market orientation and strategic innovation orientation help to contribute towards augmentation of firms' competencies, i.e., pharmaceutical companies in the present study and value in a cumulative manner through impacting sustainability in performance. A good strategy always needs to be implemented in order to result into enhanced business performance from economic, social or environmental dimensions. A market-oriented strategy complemented by innovationoriented strategy will help to realize sustainability in performance and commitment towards various stakeholders in a congruent manner. The effective marketorientation and innovation-orientation can thus provide competitive advantage to pharmaceutical firms.

\section{ACKNOWLEDGEMENT}

The author wishes to thank the West Bengal Department of Higher Education.

\section{CONFLICT OF INTEREST}

The authors declare no conflict of interest.

\section{REFERENCES}

1. Nidumolu R, Prahalad CK, Rangaswami MR. Why Sustainability Is Now the Key Driver of Innovation. Harward Business Review. 2009;87(9):57-64.

2. Hooley GJ, Greenley G, Cadogan JW, Fahy J. The performance impact of marketing resources. Journal of Business Research. 2005;58(1):18-27.

3. Morgan NA, Clark BH, Gooner R. Marketing productivity, marketing audits and systems for marketing performance assessment: Integrating multiple perspectives. Journal of Business Research. 2002;55(5):363-75.

4. KohliAK, JaworskiBJ. Market orientation: The construct, research propositions and managerial implications. Journal of Marketing. 1990;54(2):1-18.

5. Siguaw JA, Simpson PM, Enz CA. Conceptualizing innovation orientation: A framework for study and integration of innovation research. Journal of Product Innovation Management. 2006;23(6):556-74.

6. Torugsa N, O'Donohue W, Hecker R. Capabilities, Proactive CSR and Financial Performance in SMEs: Empirical Evidence from an Australian Manufacturing Industry Sector. J Bus Ethics. 2012;109(4):483-500.

7. Leszczynska A. Towards shareholders' value: an analysis of sustainability reports. Ind Manag Data Syst. 2012;112(6):911-28.

8. Sartoria S Witjes S, Campos L. Sustainability performance for Brazilian electricity power industry: An assessment integrating social, economic and environmental issues. Energy Policy 2017;111:41-51.

9. Jean B, Kim D, Chiou JS. Calantone R. Strategic orientations, joint learning and innovation generation in international customer-supplier relationships. International Business Review 2018;27(4):838-51.

10. Tannoury $M$, Attieh $Z$ The Influence of Emerging Markets on the Pharmaceutical Industry. Current Therapeutic Research. 2017;86:19-22.

11. Noble $\mathrm{CH}$, Sinha RK, Kumar A. Market orientation and alternative strategic orientations: A longitudinal assessment of performance implications. Journal of Marketing. 2002;66(4):25-39.

12. Kaynak E, Kara A. Market orientation and organizational performance: $A$ comparison of industrial versus consumer companies in main land China using market orientation scale (MARKOR). Industrial Marketing Management. 2004;33(8):743-53.

13. Hult GTM, Hurley RF, Knight GA. Innovativeness: Its antecedents and impact on business performance. Industrial Marketing Management. 2004;33(5):429-38.

14. Zhou KZ, Yim CK, Tse DK. The effects of strategic orientations on technology and market-based breakthrough innovations. Journal of Marketing. 2005;69(2):42-60.

15. Drucker P. The effective executive. Harper and Row 1966.

16. Lovett MJ, MacDonald JB. How does financial performance affect marketing? Studying the marketing-finance relationship from a dynamic perspective. Journal of the Academy of Marketing Science. 2005;33(4):476-85.

17. Mu J, Thomas E, Peng G, Anthony DB. Strategic orientation and new product development performance: The role of networking capability and networking ability. Industrial Marketing Management. 2017;64:187-201.

18. Li Y. Environmental innovation practices and performance: moderating effect of resource commitment. Journal of Cleaner Production. 2014;66:450-8.

19. Cegarra-Navarro G, Carmelo R, Gomez-Melero E, Anthony KP, Wensley. Linking social and economic responsibilities with financial performance: The role of innovation. European Management Journal. 2016;34(5):530-9.

20. Li Y, Ye F, Sheu C, Yang Q. Linking green market orientation and performance: Antecedents and processes. Journal of Cleaner Production. 2018;192:92431.

21. Narver JC, Slater SF. The effect of a market orientation on business profitability. Journal of Marketing. 1990;54(4):20-35.

22. Menguc B, Auh S. Creating a firm-level dynamic capability through capitalizing on market orientation and innovativeness. Journal of the Academy of Marketing Science. 2006;34(1):63-73.

23. Jin Z, Hewitt-Dundas N, Thompson NJ. Innovativeness and performance: Evidence from manufacturing sectors. Journal of Strategic Marketing. 2004;12(4):255-66.

24. Biswas A, Roy M. Green marketing perception as an antecedent for organizational environmental image creation: A study in an emerging economy. IJER. 2016;13(5).

25. Biswas A. A consumption value-gap analysis for sustainable consumption. Environ Sci Pollut Re. 2017;24(8)7714-25. 
26. Lee KH, Saen R. Measuring corporate sustainability management: a data envelopment analysis approach. Int J Prod Econ. 2012;140(1):219-26.

27. Gatti L, Seele P. Evidence for the prevalence of the sustainability concept in European corporate responsibility reporting. Sustain Sci. 2014;9(1):89-102.

28. Hart SL, Milstein MB. Creating Sustainable Value. Academy of Management Executive. 2003;17(2):56-67.

29. Ambec S, Lanoie P. When and why does it pay to be green?. Academy of Management Perspectives. 2008;23:45-62.

30. Elkington J. Towards the sustainable corporation. California Management Review. 1994;90.
31. Zhu Q, Sarkis J. Relationships between operational practices and performance among early adopters of green supply chain management practices in Chinese manufacturing enterprises, Journal of Operations Management. 2004;22(3):265-89.

32. Orlitzky M. Corporate social performance and financial performance, A Research synthesis in, the Oxford Handbook of Corporate Social Responsibility. Oxford University, Press: New York. 2008.

33. Diamantopoulos A, Siguaw A. Introducing Lisrel. SAGE Publications. 2000.

Cite this article: Biswas A. Effect of Strategic Marketing on Sustainable Business Performance- A Study of Pharmaceutical Industries in India. Indian J of Pharmaceutical Education and Research. 2019;53(1):21-7. 